\title{
Intravenous Administration of Phosphorylated Acid $\alpha$-Glucosidase Leads to Uptake of Enzyme in Heart and Skeletal Muscle of Mice
}

\author{
A. T. Van der Ploeg, ${ }^{\star *}$ M. A. Kroos, ${ }^{*}$ R. Willemsen, ${ }^{*}$ N. H. C. Brons, ${ }^{*}$ and A. J. J. Reuser* \\ ${ }^{*}$ Department of Cell Biology and Genetics, Erasmus University, Rotterdam, The Netherlands; ${ }^{\ddagger}$ Sophia Children's Hospital, Rotterdam; \\ and ${ }^{\S}$ Department of Clinical Immunology, University of Groningen, Groningen, The Netherlands
}

\begin{abstract}
The lysosomal storage disorder glycogenosis type II is caused by acid $\alpha$-glucosidase deficiency. In this study we have investigated the possible applicability of mannose 6-phosphate receptor-mediated enzyme replacement therapy to correct the enzyme deficiency in the most affected tissues. Bovine testes acid $\alpha$-glucosidase containing phosphorylated mannose residues was intravenously administered to mice and found to be taken up by heart (70\% increase of activity) and skeletal muscle (43\% increase); the major target organs. The uptake of nonphosphorylated human placenta acid $\alpha$-glucosidase by heart and skeletal muscle appeared to be significantly less efficient, whereas uptake of dephosphorylated bovine testes enzyme was not detectable. The phosphorylated bovine testes acid $\alpha$-glucosidase remained present in mouse skeletal muscle up to 9-15 d after administration, with a half-life of 2-4 d. Besides being measured in skeletal muscle and heart, uptake of phosphorylated bovine testes and nonphosphorylated human placenta acid $\alpha$ glucosidase was measured in several other organs, but not in brain. The increase of acid $\alpha$-glucosidase activity was highest in liver and spleen. We concluded that application of mannose 6-phosphate receptor-mediated enzyme replacement therapy may offer new perspectives for treatment of glycogenosis type II. (J. Clin. Invest. 1991. 87:513-518.) Key words: lysosome • $\alpha$-glucosidase $\bullet$ glycogenosis $\bullet$ enzyme therapy
\end{abstract}

\section{Introduction}

Glycogenosis type II is one of the more than 30 lysosomal storage disorders, and is caused by inherited deficiency of acid $\alpha$-glucosidase $(1,2)$. Patients with an early onset infantile form of this disease have little or no residual enzyme activity (3-8). They present shortly after birth with severe hypotonia and cardiorespiratory insufficiency. Their life expectancy is less than two years. In late onset variants skeletal muscle weakness is the major feature. The heart is mostly not affected. Respiratory failure is the major cause of death. In these juvenile and adult phenotypes, acid $\alpha$-glucosidase activities up to $\sim 20 \%$ of normal have been reported (3-8).

In the early 1970s much thought was given to the idea that lysosomal storage diseases could possibly be cured by enzyme

Address reprint requests to Dr. A. J. J. Reuser, Department of Cell Biology and Genetics, Erasmus University, P.O. Box 1738, 3000 DR Rotterdam, The Netherlands. 1990

Received for publication 26 June 1989 and in revised form 25 July

J. Clin. Invest.

(c) The American Society for Clinical Investigation, Inc.

0021-9738/91/02/0513/06 \$2.00

Volume 87, February 1991, 513-518 replacement therapy (9-13). This view gained interest when degradation of storage compounds was demonstrated after uptake of enzyme by cultured fibroblasts from patients with mucopolysaccharidoses (14-16). But the number of clinical trials remained small for the obvious reason that highly purified lysosomal enzymes were only available in very limited amounts. Moreover, infused enzyme was found to be captured predominantly by the liver and the spleen when administered to animals or to patients. Uptake of enzyme in other organs was hardly observed (9-13, 17-20). Attempts at enzyme replacement therapy for glycogenosis type II have failed (21-23).

To circumvent these problems alternative approaches were taken to supply the lacking enzymes, for instance via cell or tissue transplantation (24-27), plasma transfusion (28), and bone marrow transplantation (29-32). The last of these methods attracts, at present, most attention, and seems promising for treatment of those diseases in which storage material accumulates in macrophages. Encouraging results have been reported in Gaucher disease type 1 and Hurler disease, but the long-term beneficial effects of bone marrow transplantation as therapy for lysosomal storage disorders need further evaluation (29-32). There is, unfortunately, little reason to be optimistic about the curative effect of bone marrow transplantation in glycogenosis type II. The reported attempts at treatment of patients with the severe infantile form of this disease were unsuccessful, while application of bone marrow transplantation in adult glycogenosis type II is not advised considering the risks of the procedure $(31,33,34)$.

With this in mind we started to explore the feasibility of receptor-mediated enzyme replacement therapy for glycogenosis type II, using the $270-\mathrm{kD}$ mannose 6-phosphate receptor, exposed on the cell surface of cardiomyocytes and skeletal muscle cells, as enzyme target. This receptor was first recognized for its function in endocytosis of mannose 6-phosphate containing lysosomal enzymes $(35,36)$, but is presently known to be also involved in the intracellular transport of newly synthesized enzymes to lysosomes (37). Another quite different function of this receptor is binding of insulin-like growth factor II $(38-40)$.

In previous studies we have shown that mannose 6-phosphate-containing acid $\alpha$-glucosidases, isolated from human urine and bovine testes, are taken up efficiently by cultured muscle cells and fibroblasts from patients with glycogenosis type II. As a result, the excessive amount of lysosomal glycogen is degraded $(7,8,41,42)$. In this study we have determined the fate of intravenously injected mannose 6-phosphate containing acid $\alpha$-glucosidase in mice.

\section{Methods}

Enzyme source and tissue preparation. Mannose 6-phosphate containing acid $\alpha$-glucosidase was purified from bovine testes (sp act $364 \mu \mathrm{mol}$ 
methylumbelliferone $(\mathrm{MU})^{1} / \mathrm{mg} / \mathrm{h}$ ), and a nonphosphorylated form of acid $\alpha$-glucosidase from human placenta (sp act $392 \mu \mathrm{mol} \mathrm{MU} / \mathrm{mg}$ per h) $(43,44,45)$. The capacity of these enzymes to bind to mannose 6-phosphate receptors was tested as described before $(7,8,41)$. Uptake of bovine testes acid $\alpha$-glucosidase by cultured human fibroblasts was found to be $\sim 160$-fold more efficient than uptake of human placenta enzyme, and was $98 \%$ inhibited by $5 \mathrm{mM}$ mannose 6-phosphate.

In a separate series of experiments purified bovine testes acid $\alpha$-glucosidase was dephosphorylated by incubation for $16 \mathrm{~h}$, at $37^{\circ} \mathrm{C}$, in 0.1 $\mathrm{M}$ ammoniumbicarbonate, $\mathrm{pH} 7.0$, containing $75 \mathrm{U}$ of immobilized alkaline phosphatase (Sigma Chemical Co., St. Louis, MO). As a control, a second lot of enzyme was incubated under identical conditions but without alkaline phosphatase. In both cases the catalytic activity was lost. The apparent molecular mass of the enzyme remained the same. The uptake of phosphorylated and dephosphorylated enzyme by cultured fibroblasts was tested by immunoblotting as described below.

The different enzyme preparations were intravenously administered to 6-wk old Swiss mice $(30 \mathrm{~g})$ via the tail veins. After $24 \mathrm{~h}$ or longer periods the animals were anesthetized, and thoracotomy was performed (46). A heparinized cannula connected to a perfusion apparatus was inserted in the left ventricle, and the right atrium was disrupted. The animals were perfused with $10 \mathrm{ml}$ of a $0.1 \%$ procain$\mathrm{HCl}$ solution in PBS, pH 7.2 , at $37^{\circ} \mathrm{C}$. Brain, liver, spleen, kidneys, heart, lungs, and muscles (soleus, quadriceps, and pectoral muscles) were then quickly removed, frozen in liquid nitrogen, and stored at $-70^{\circ} \mathrm{C}$.

Biochemical assays. Tissue specimens (0.1-0.2 $\mathrm{g}$ wet wt) were homogenized in $400 \mu$ l of distilled water, using a Potter Elvejem homogenizer at $1,300 \mathrm{rpm}$ and a sonicator (Measuring and Scientific Equipment, Loughborough, UK). Cell debris was removed by centrifugation at $15,000 \mathrm{~g}$. The protein concentration of the samples was measured according to Lowry et al. (47), and the acid $\alpha$-glucosidase activities were determined as previously described, using 4-methylumbelliferyl$\alpha$-D-glucopyranoside as substrate (48). Enzyme activities are expressed in nanomoles MU liberated per hour.

Immunoprecipitation. Antisera against bovine testes and human placenta acid $\alpha$-glucosidase were raised in Swiss mice to discriminate between infused exogenous enzymes and mouse endogenous acid $\alpha$ glucosidase. These antisera precipitate $90-95 \%$ of bovine testes and human placenta acid $\alpha$-glucosidase, but $<2 \%$ of the enzyme from mouse tissues (49). Tissue homogenates from mice injected with acid $\alpha$-glucosidase and from control animals injected with PBS (10 mM sodium phosphate and $0.9 \% \mathrm{NaCl}$ ), were diluted in PBS, pH 6.8, containing $1 \mathrm{mg} / \mathrm{ml} \mathrm{BSA}$ to an acid $\alpha$-glucosidase activity of $1 \mu \mathrm{mol} \mathrm{MU} / \mathrm{h}$ per $20 \mu \mathrm{l}$. Purified enzyme preparations from bovine testes and human placenta were diluted in the same way. Samples of $20 \mu \mathrm{l}$ were incubated overnight at $4^{\circ} \mathrm{C}$ with $10 \mu \mathrm{l}$ of a 400 -fold diluted antiserum in PBS/ BSA or with PBS/BSA alone. Staphylococcus $A$ membranes (10 $\mu$; Bethesda Research Laboratories, Gaithersburg, MD) were added to precipitate immune complexes. The membranes were spun down at $15,000 \mathrm{~g}$, and the acid $\alpha$-glucosidase activity was measured in the supernatant, and on the membranes after six washes with PBS/BSA.

Immunoblotting. Tissue homogenates from control mice, and mice injected with bovine testes acid $\alpha$-glucosidase were incubated with a mouse antiserum raised against this enzyme. Immune complexes were precipitated with protein A Sepharose beads $(50 \mu \mathrm{l}$ of a $1: 1$ suspension in PBS) at $4^{\circ} \mathrm{C}$. The beads were washed four times with PBS, and bound complexes were dissolved by heating for $10 \mathrm{~min}$ at $90^{\circ} \mathrm{C}$ in sample buffer ( $125 \mathrm{mM}$ Tris- $\mathrm{HCl}, \mathrm{pH} 6.6,2 \mathrm{M}$ glycerol, 4\% SDS, $0.6 \%$ mercaptoethanol, and $0.05 \%$ bromophenol blue). Samples were subsequently subjected to electrophoresis in $10 \%$ polyacrylamide gels and blotted onto nitrocellulose $(50,51)$. Bovine testes acid $\alpha$-glucosidase was visualized with mouse antiserum specifically raised against this enzyme, using ${ }^{125}$ I-labeled protein $A$ as radioactive probe (51). In an alternative procedure the immune complexes were visualized with goat

1. Abbreviation used in this paper: MU, methylumbelliferone. antibodies against mouse IgG conjugated to alkaline phosphatase (Tago, Inc., Burlingame, CA).

\section{Results}

In a pilot experiment, two 6-wk old mice (weight, $30 \mathrm{~g}$ ) were injected with 90 and $180 \mu \mathrm{g}$ (equivalent to 32 and $64 \mu \mathrm{mol}$ $\mathrm{MU} / \mathrm{h}$ ) of mannose 6-phosphate containing bovine testes acid $\alpha$-glucosidase. After $24 \mathrm{~h}$ the mice were killed and the activity of bovine testes acid $\alpha$-glucosidase in the mouse organs was measured by means of species-specific enzyme immunoprecipitation. (The antiserum used for this purpose precipitates 90 $95 \%$ of bovine testes acid $\alpha$-glucosidase, but $<2 \%$ of the endogenous mouse enzyme.) Table I shows the percentage of precipitable acid $\alpha$-glucosidase activity in mouse tissues after enzyme administration, as well as the increase of enzyme activity per tissue. Brain did not contain a measurable amount of infused enzyme, but in all other tissues a dose-dependent uptake of bovine testes acid $\alpha$-glucosidase was observed. The effect of enzyme infusion was most pronounced in liver and spleen, but was also noted in muscle, heart, lung, and kidney.

The molecular mass of the immunoprecipitated acid $\alpha$-glucosidase was determined to further define the origin of the enzyme activity in the mouse tissues. To this end, the enzyme precipitated from muscle and liver was subjected to polyacrylamide gel electrophoresis in the presence of SDS and analyzed by immunoblotting. The results are presented in Fig. 1. The precipitated enzyme had the same molecular mass $(70 \mathrm{kD})$ as the administered bovine testes acid $\alpha$-glucosidase, and this enzyme species was only detectable in mouse tissues after enzyme infusion (lanes 2 and 4). The cross-reactive proteins of higher relative molecular weight (lanes 2 and 3 ) are of mouse origin.

In a following experiment the stability of endocytosed enzyme was studied. For this purpose 13 mice were injected with $180 \mu \mathrm{g}$ of purified bovine testes acid $\alpha$-glucosidase. The enzyme remained detectable in serum until $1 \mathrm{~h}$ after injection. The animals were killed on day 1, 3, 6, 9, and 15 after enzyme infusion, and the increase of acid $\alpha$-glucosidase activity in the various tissues was determined as described above via immunoprecipitation of bovine testes acid $\alpha$-glucosidase (Table II). The activities measured $1 \mathrm{~d}$ after enzyme administration corresponded with those obtained in the pilot experiment. No en-

Table I. Dose-dependent Uptake of Bovine Testes Acid $\alpha$-Glucosidase in Mouse Organs

\begin{tabular}{lcccc}
\hline & \multicolumn{2}{c}{$\begin{array}{c}\text { Precipitable enzyme } \\
\text { activity }(\%)^{*}\end{array}$} & \multicolumn{2}{c}{$\begin{array}{c}\text { Increase of enzyme } \\
\text { activity }(\%)^{*}\end{array}$} \\
\hline Injected dose $\ldots$ & $90 \mu g$ & $180 \mu g$ & $90 \mu g$ & $180 \mu g$ \\
Brain & 0 & 0 & 0 & 0 \\
Liver & 50 & 70 & 100 & 233 \\
Spleen & 64 & 75 & 177 & 300 \\
Heart & 17 & 36 & 20 & 56 \\
Muscle & 14 & 32 & 16 & 44 \\
Lung & 8 & 35 & 9 & 54 \\
Kidney & 7 & 11 & 8 & 12 \\
& & & &
\end{tabular}

* The activity precipitable with mouse antiserum against bovine testes acid $\alpha$-glucosidase is expressed as percentage of the total acid $\alpha$-glucosidase activities in the tissue homogenates.

₹ The increase of acid $\alpha$-glucosidase activity in mouse tissues is expressed as percentage of the tissue specific endogenous enzyme activity. 


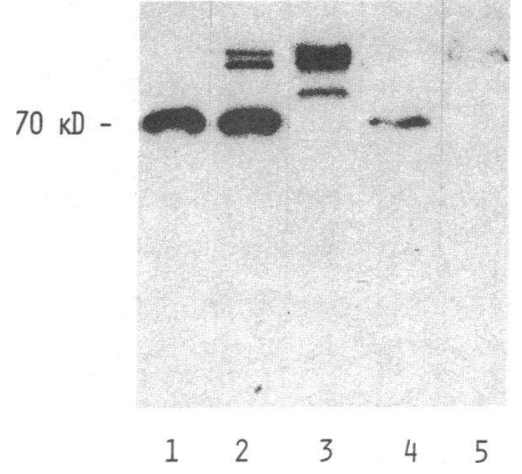

bovine enzyme. ${ }^{125}$ I-protein A was used as radioactive probe. Lane 1 , purified bovine testes acid $\alpha$-glucosidase; lane 2, mouse liver after enzyme administration; lane 3, control mouse liver; lane 4, mouse skeletal muscle after enzyme administration; lane 5, control mouse skeletal muscle.

zyme uptake was recorded in brain, while the increase of acid $\alpha$-glucosidase activity in liver and spleen was highest (two to four times the endogenous activity). Enzyme activities in skele- tal muscle, heart, and lung showed an increase of 43.4, 70.6, and $64.5 \%$, respectively. Little uptake of enzyme was measured in kidney. In the following period of $14 \mathrm{~d}$ a gradual decline of bovine testes enzyme activity was measured in all tissues. But even at day 15 some activity of bovine testes acid $\alpha$-glucosidase remained detectable in liver and muscle (Table II), while relatively high exogenous enzyme activities were still present in the spleen. From these figures we calculated that the half-life of bovine testes acid $\alpha$-glucosidase in the different tissues varied from 2 to $4 \mathrm{~d}$.

In a third series of experiments five animals were injected with $180 \mu \mathrm{g}$ of acid $\alpha$-glucosidase from human placenta lacking the mannose 6-phosphate recognition marker to study the role of the mannose 6-phosphate receptor in enzyme targeting. These mice were killed after $1 \mathrm{~d}$ and the uptake of human placenta and bovine testes acid $\alpha$-glucosidase was compared. The results are included in Table II (day 1). It appeared that the human placenta and the bovine testes enzymes were taken up with about the same efficiency by liver, spleen, and lungs. However, administration of mannose 6-phosphate containing bovine testes acid $\alpha$-glucosidase led to a two to three times higher uptake in heart and skeletal muscle than infusion of the same amount of enzyme isolated from human placenta.

Table II. Increase of Acid $\alpha$-Glucosidase Activity in Mouse Organs after Uptake of Exogenous Enzyme*

\begin{tabular}{|c|c|c|c|c|c|c|}
\hline Tissue & $\begin{array}{l}\text { Enzyme } \\
\text { source }\end{array}$ & 1 & 3 & 6 & 9 & 15 \\
\hline & & & & $d$ & & \\
\hline Brain & $\begin{array}{l}\text { b.t. } \\
\text { h.pl. }\end{array}$ & $\begin{array}{c}0 \\
(n=3) \\
0 \\
(n=2)\end{array}$ & 0 & 0 & 0 & 0 \\
\hline Liver & $\begin{array}{l}\text { b.t. } \\
\text { h.pl. }\end{array}$ & $\begin{array}{c}282 \pm 70 \\
(n=6) \\
215 \pm 70 \\
(n=5)\end{array}$ & $269 \pm 47$ & $79 \pm 10$ & 100 & $6.5 \pm 1.5$ \\
\hline Spleen & $\begin{array}{l}\text { b.t. } \\
\text { h.pl. }\end{array}$ & $\begin{array}{c}341 \pm 74 \\
(n=5) \\
274 \pm 95 \\
(n=5)\end{array}$ & $274 \pm 144$ & $118.5 \pm 14.5$ & 72 & $26.5 \pm 0.5$ \\
\hline Heart & $\begin{array}{l}\text { b.t. } \\
\text { h.pl. }\end{array}$ & $\begin{array}{c}70.6 \pm 8 \\
(n=5) \\
34.6 \pm 6.5 \\
(n=5)\end{array}$ & $39 \pm 7$ & $14 \pm 9$ & 0 & 0 \\
\hline Muscle & $\begin{array}{l}\text { b.t. } \\
\text { h.pl. }\end{array}$ & $\begin{array}{c}43.4 \pm 12.1 \\
(n=6 ; x=16) \\
13.2 \pm 5.4 \\
(n=5 ; x=11)\end{array}$ & $\begin{array}{r}23.6 \pm 8.4 \\
(x=10)\end{array}$ & $\begin{array}{l}16 \pm 6.7 \\
(x=6)\end{array}$ & $\begin{array}{l}2.6 \pm 1.4 \\
(x=5)\end{array}$ & $\begin{array}{l}1.1 \pm 0.8 \\
(x=4)\end{array}$ \\
\hline Lung & $\begin{array}{l}\text { b.t. } \\
\text { h.pl. }\end{array}$ & $\begin{array}{c}64.5 \pm 24.5 \\
(n=2) \\
49 \pm 8 \\
(n=2)\end{array}$ & $28.5 \pm 10.5$ & $11 \pm 7$ & 0 & 0 \\
\hline Kidney & $\begin{array}{l}\text { b.t. } \\
\text { h.pl. }\end{array}$ & $\begin{array}{c}8 \pm 1 \\
(n=2) \\
8 \pm 3.6 \\
(n=2)\end{array}$ & $6 \pm 5$ & 0 & 0 & 0 \\
\hline
\end{tabular}

* The increase is expressed as percentage of the tissue-specific endogenous activity. $180 \mu \mathrm{g}$ of acid $\alpha$-glucosidase from bovine testes (b.t.) or human placenta (h.pl.) was injected. $n$, number of mice (two animals were tested on day 3,6 , and 15 , and one on day 9); $x$, number of muscles analyzed including quadriceps, soleus, and pectoral muscles. 
To exclude the possibility that the differences in the fates of the human placenta and the bovine testes acid $\alpha$-glucosidase were due to factors other than the mannose 6-phosphate content of the sugar chains the following experiment was conducted. Bovine testes acid $\alpha$-glucosidase was dephosphorylated by incubation with alkaline phosphatase. The effect of this treatment was assayed by comparing the uptake efficiency of phosphorylated and dephosphorylated enzyme by cultured fibroblasts from a patient with a complete enzyme deficiency. Immunoblot analysis revealed that alkaline phosphatase treatment abolished the uptake of bovine testes acid $\alpha$-glucosidase by fibroblasts completely. The condition of alkaline phosphatase treatment per se did not affect the efficiency of enzyme uptake. Six mice were injected with dephosphorylated enzyme, six with phosphorylated enzyme, and a third group with PBS. Of each group, three animals were killed $1 \mathrm{~d}$ after infusion and three on day 3. Homogenates were made of the quadriceps and pectoral muscles and bovine testes acid $\alpha$-glucosidase was immunoprecipitated, as described above. Polyacrylamide gel electrophoresis followed by immunoblotting was performed to analyze these samples for the presence of bovine testes enzyme. The results obtained are shown in Fig. $2 A$ (pectoral muscle) and Fig. $2 B$ (quadriceps muscle). The $70-\mathrm{kD}$ bovine testes acid $\alpha$-glucosidase is only detectable in skeletal muscle tissue after injection of mannose 6-phosphate containing enzyme (lanes 3 and 6 ).

One of the animals infused with bovine testes acid $\alpha$-gluco-

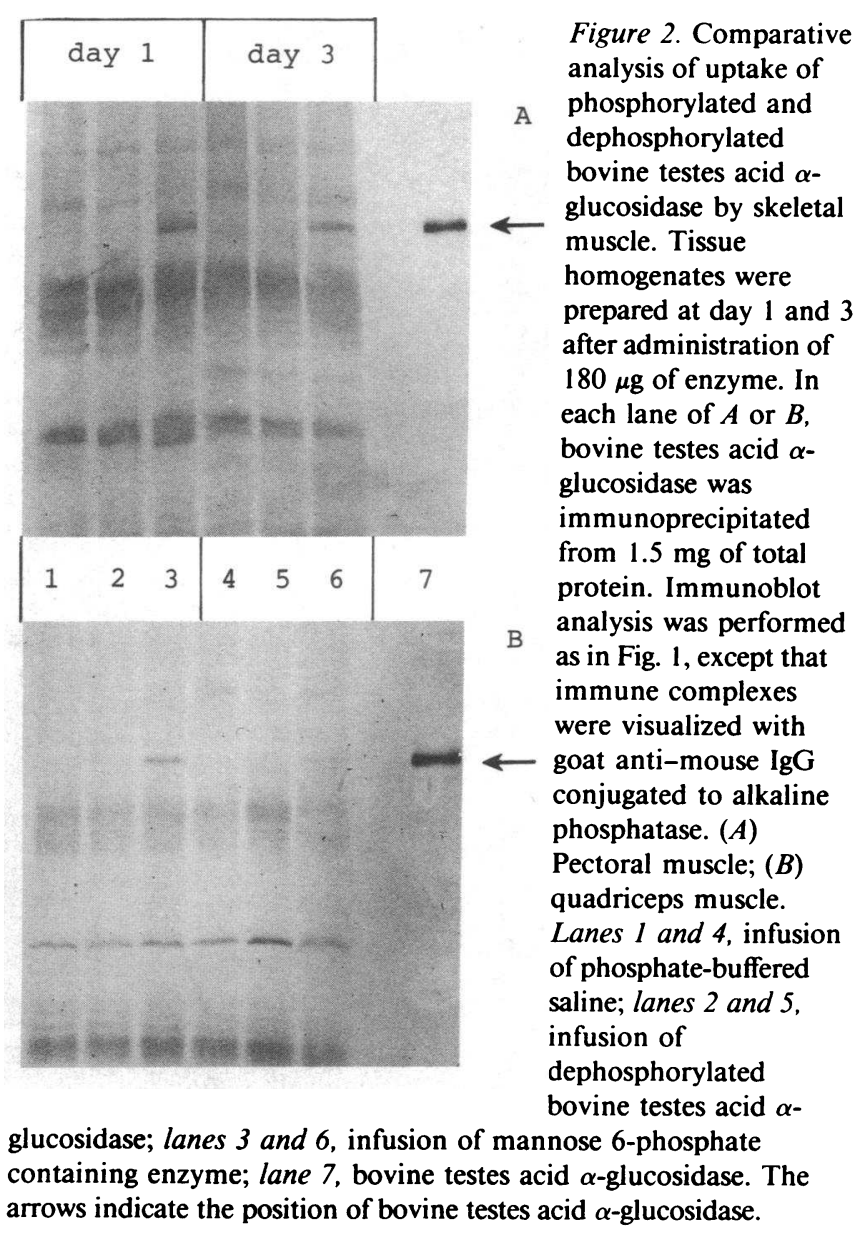

sidase appeared to be pregnant at autopsy. This gave us the opportunity to investigate whether intravenously injected enzyme could cross the placental barrier. Brain, liver, spleen, heart, skeletal muscle, and kidney from six 17-d old fetuses were analyzed $24 \mathrm{~h}$ after enzyme infusion, but no increase of enzyme activity was measured in any of the fetal tissues. The experiment was repeated with two more pregnant mice and the same results were obtained.

\section{Discussion}

This study was conducted to investigate the feasibility of mannose 6-phosphate receptor-mediated enzyme replacement therapy for glycogenosis type II. Mannose 6-phosphate containing acid $\alpha$-glucosidase isolated from bovine testes is shown to be taken up by the major target organs after intravenous injection. A $43 \%$ increase of acid $\alpha$-glucosidase activity in skeletal muscle and a $70 \%$ increase in heart was measured, notably higher than obtained with a similar dose $(180 \mu \mathrm{g})$ of nonphosphorylated acid $\alpha$-glucosidase purified from human placenta. Uptake of bovine testes $\alpha$-glucosidase becomes undetectable after dephosphorylation. These results suggest that the mannose 6phosphate receptor facilitates enzyme uptake in skeletal muscle and cardiac tissue. Also in a recent series of experiments in which isolated rat hearts were perfused with different forms of acid $\alpha$-glucosidase we were able to demonstrate a more efficient uptake of mannose 6-phosphate containing enzyme (52). The way of transport of lysosomal enzymes from the plasma to the target cells remains of interest. Suggestive evidence was recently obtained that plasmalemmal vesicles are involved (53).

The major fraction of infused enzyme is captured by the liver and the spleen, with little distinction between phosphorylated and nonphosphorylated enzyme species. It is likely that most activity in these tissues resides in macrophages known to express both the mannose and the mannose 6-phosphate receptors (54). Brain remains completely devoid of exogenous enzyme activity which is obviously due to the blood brain barrier $(55,56)$. Thus, our results are in general agreement with earlier observations on the fate of infused enzymes in clinical trials and in animal models $(17-20,57,58)$. Passage across the placental barrier separating the maternal and fetal circulation is apparently not possible either, since infused enzyme was only recovered in maternal and not in fetal tissues.

To evaluate the practical significance of our study for enzyme replacement therapy in glycogenosis type II, the following considerations are important. Most patients with late onset glycogenosis type II have a residual acid $\alpha$-glucosidase activity between 10 and $20 \%$ of the average control value (3-8). This suggests that lysosomal glycogen storage does not occur when the residual enzyme activity is more than $\sim 20 \%$. Model experiments with cultured muscle cells support this assumption $(7,8)$. Therefore, a slight increase of acid $\alpha$-glucosidase activity might be sufficient to prevent or reverse lysosomal glycogen storage and clinical symptoms.

In this study a $43 \%$ increase of activity is measured in mouse skeletal muscle one day after enzyme administration. Six days later the level of activity is still $10-20 \%$ above normal, which would in principle be sufficient to compensate the enzyme deficiency in adult glycogenosis type II. Our experiments therefore indicate that application of enzyme replacement ther- 
apy might be successful. But it is evident that efficient procedures have to be developed for large scale production of human mannose 6-phosphate containing acid $\alpha$-glucosidase before it can come to application of enzyme replacement therapy in clinical trials. The mice used in our studies received 90-180 $\mu \mathrm{g}$ of purified enzyme. Calculated by body weight, $200-400 \mathrm{mg}$ would be the equivalent amount of enzyme needed to obtain the same effect in humans. This is far more than the amount of acid $\alpha$-glucosidase administered in the past to patients with infantile glycogenosis type II. Moreover, the enzyme used in these early clinical trials had been purified from human placenta and therefore did not contain the mannose 6-phosphate recognition marker essential for efficient uptake in heart and skeletal muscle. This explains in retrospect why no curative effect was obtained.

When the estimated half-life of bovine testes acid $\alpha$-glucosidase in mouse tissues is representative for the half-life of human enzyme taken up by human tissues this would mean that an infusion of $200-400 \mathrm{mg}$ of enzyme is required once every week for treatment of adult glycogenosis type II. Isolation of this amount of enzyme from human tissues is not within technical reach, but production of a sufficient amount of enzyme may become possible by using cloned human acid $\alpha$-glucosidase cDNA (59). We are presently exploring the feasibility of such an approach. In view of our findings and the predictable technological developments we think that the original idea of enzyme replacement therapy for treatment of lysosomal storage diseases deserves new attention.

While this paper was in preparation Barton et al. reported on the clinical improvement of a patient with Gaucher disease type I after long-term treatment with glucocerebrosidase (60).

\section{Acknowledgments}

The authors wish to thank Prof. Dr. H. Galjaard for continuous support, M. Scholte for technical assistance, J. Fengler, M. Kuit, and P. W. Visser for preparation of figures and photography, and J. Lokker for secretarial assistance.

Financial support was obtained from the Prinses Beatrix Fonds.

\section{References}

1. Hers, H. G. 1963. $\alpha$-Glucosidase deficiency in generalized glycogen-storage disease (Pompe's disease). Biochem. J. 86:11-16.

2. Howell, R. R., and J. C. Williams. 1983. The glycogen storage diseases. In The Metabolic Basis of Inherited Disease. J. B. Stanbury, J. B. Wijngaarden, D. S. Fredrickson, J. L. Goldstein, and M. S. Brown, editors. McGraw-Hill, Inc., New York. 141-166.

3. Mehler, M., and S. DiMauro. 1977. Residual acid maltase activity in lateonset acid maltase deficiency. Neurology. 27:178-184.

4. Shanske, S., S. Servidei, M. Bowman, and S. DiMauro. 1986. Biochemical studies in muscle biopsies from 45 patients with acid maltase deficiency (AMD). Muscle \& Nerve. 9:196a. (Abstr.)

5. Reuser, A. J. J., J. F. Koster, A. Hoogeveen, and H. Galjaard. 1978. Biochemical, immunological, and cell genetic studies in glycogenosis type II. Am. J. Hum. Genet. 30:132-143.

6. Reuser, A. J. J., M. Kroos, R. Willemsen, D. Swallow, J. M. Tager, and H. Galjaard. 1987. Clinical diversity in glycogenosis type II. Biosynthesis and in situ localization of acid $\alpha$-glucosidase in mutant fibroblasts. J. Clin. Invest. 79:16891699.

7. Van der Ploeg, A. T., M. Kroos, J. M. Van Dongen, W. J. Visser, P. A. Bolhuis, M. C. B. Loonen, and A. J. J. Reuser. 1987. Breakdown of lysosomal glycogen in cultured fibroblasts from glycogenosis type II patients after uptake of acid $\alpha$-glucosidase. J. Neurol. Sci. 79:327-336.

8. Van der Ploeg, A. T., P. A. Bolhuis, R. A. Wolterman, J. W. Visser, M. C. B. Loonen, H. F. M. Busch, and A. J. J. Reuser. 1988. Prospect for enzyme therapy in glycogenosis II variants: a study on cultured muscle cells. J. Neurol. 235:392396.
9. Bergsma, D., R. J. Desnick, R. W. Bernlohr, and W. Krivit, editors. 1973. Enzyme therapy in genetic diseases. Birth Defects Original Article Series. Vol. 2. Williams \& Wilkins Co., Baltimore.

10. Brady, R. O., J. F. Tallman, W. G. Johnson, A. E. Gal, W. R. Leahy, J. M. Quirk, and A. S. Dekaban. 1973. Replacement therapy for inherited enzyme deficiency: use of purified ceramide-trihexosidase in Fabry's disease. $N$. Engl. J. Med. 289:9-14.

11. Tager, J. M., G. J. M. Hooghwinkel, and W. T. Daems, editors. 1974. Enzyme Therapy in Lysosomal Storage Diseases. North-Holland Publishing Co., Amsterdam.

12. Desnick, R. J., S. R. Thorpe, and M. B. Fiddler. 1976. Toward enzyme therapy for lysosomal storage diseases. Physiol. Rev. 56:57-99.

13. Desnick, R. J., editor. 1980. Enzyme therapy in genetic diseases:2. Birth Defects Original Article Series. Vol. 16. Alan R. Liss, Inc., New York.

14. Neufeld, E. F., and M. J. Cantz. 1971. Corrective factors for inborn errors of mucopolysaccharide metabolism. Ann. NY Acad. Sci. 179:580-587.

15. Hickman, S., L. J. Shapiro, and E. F. Neufeld. 1974. A recognition marker required for uptake of a lysosomal enzyme by cultured fibroblasts. Biochem. Biophys. Res. Commun. 57:55-61.

16. Lagunoff, D., D. M. Nicol, and P. Pritzl. 1973. Uptake of $\beta$-glucuronidase by deficient human fibroblasts. Lab. Invest. 29:449-453.

17. Schlesinger, P., J. S. Rodman, M. Frey, S. Lang, and P. Stahl. 1976. Clearance of lysosomal hydrolases following intravenous infusion. The role of liver in the clearance of $\beta$-glucuronidase and $N$-acetyl- $\beta$-D-glucosaminidase. Arch. Biochem. Biophys. 177:606-614.

18. Stahl, P., H. Six, J. S. Rodman, P. Schlesinger, D. R. P. Tulsiani, and O. Touster. 1976. Evidence for specific recognition sites mediating clearance of lysosomal enzymes in vivo. Proc. Natl, Acad. Sci. USA. 73:4045-4049.

19. Achord, D., F. Brot, A. Gonzalez-Noriega, W. Sly, and P. Stahl. 1977. Human $\beta$-glucuronidase. II. Fate of infused human placental $\beta$-glucuronidase in the rat. Pediatr. Res. 11:816-822.

20. Achord, D. T., F. E. Brot, C. E. Bell, and W. S. Sly. 1978. Human $\beta$-glucuronidase: in vivo clearance and in vitro uptake by a glycoprotein recognition system on reticuloendothelial cells. Cell. 15:269-278.

21. Baudhuin, P., H. G. Hers, and H. Loeb. 1964. An electronmicroscopic and biochemical study of type II glycogenosis. Lab. Invest. 13:1139-1152.

22. De Barsy, T., P. Jacquemin, F. Van Hoof, and H. G. Hers. 1973. Enzyme replacement in Pompe disease: an attempt with purified human acid $\alpha$-glucosidase. In Enzyme Therapy in Genetic Diseases. Birth Defects Original Article Series. Vol. 9. R. J. Desnick, R. W. Bernlohr, and K. Krivit, editors. Williams \& Wilkins, Baltimore. 184-190.

23. Hug, G., W. K. Schubert, and G. Chuck. 1968. Type II glycogenosis: treatment with extract from Aspergillus Niger. Clin. Res. 16:345a (Abstr.)

24. Knudson, A. G., N. Di Ferrante, and J. E. Curtis. 1971. Effect of leukocyte transfusion in a child with type II mucopolysaccharidosis. Proc. Natl. Acad. Sci. USA. 68:1738-1741.

25. Dean, M. F., and M. Muir. 1975. Increased breakdown of glycosaminoglycans and appearance of corrective enzyme after skin transplants in Hunter syndrome. Nature (Lond.). 257:609-612.

26. Howell, J., P. R. Dorling, P. N. DiMarco, and E. G. Taylor. 1987. Multiple implantation of normal amnion into cattle with generalized glycogenosis type II. J. Inherited Metab. Dis. 10:3-10.

27. Scaggiante, B., A. Pineschi, M. Sustersich, M. Andolina, E. Agosti, and D. Romeo. 1987. Successful therapy of Niemann-Pick disease by implantation of human amniotic membrane. Transplantation (Baltimore). 44:59-61.

28. Di Ferrante, N., B. L. Nichols, P. V. Donnelly, G. Neri, R. Hrgovcic, and R. K. Berglund. 1971. Induced degradation of glycosaminoglycans in Hurler's and Hunter's syndromes by plasma infusion. Proc. Natl. Acad. Sci. USA. 68:303307.

29. Krivit, W., and N. W. Paul, editors. 1986. Bone Marrow Transplantation for Treatment of Lysosomal Storage Diseases. Alan R. Liss, Inc., New York.

30. Hobbs, J. R. 1987. Experience with bone marrow transplantation for inborn errors of metabolism. Enzyme (Basel). 38:194-206.

31. Hobbs, J. R. 1988. Displacement bone marrow transplantation and immunoprophylaxis for genetic diseases. Adv. Intern. Med. 33:81-118.

32. Ringden, O., C. G. Groth, A. Erikson, L. Backman, S. Granqvist, J. E. Mansson, and L. Svennerholm. 1988. Long-term follow-up of the first successful bone marrow transplantation in Gaucher disease. Transplantation (Baltimore). 46:66-70.

33. Watson, J. G., D. Gardner-Medwin, M. E. Goldfinch, and A. D. J. Pearson. 1986. Bone marrow transplantation for glycogen storage disease type II (Pompe's disease). N. Engl. J. Med. 314:385.

34. Harris, R. E., D. Hannon, C. Vogler, and G. Hug. 1986. Bone Marrow transplantation in type Ila glycogen storage disease. In Bone Marrow Transplantation for Treatment of Lysosomal Storage Diseases. W. Krivit and N. W. Paul, editors. Alan R. Liss, Inc., New York. 119-132.

35. Kaplan, A., D. T. Achord, and W. S. Sly. 1977. Phosphohexosyl components of a lysosomal enzyme are recognized by pinocytosis receptors on human fibroblasts. Proc. Natl. Acad. Sci. USA. 74:2026-2030. 
36. Sando, G. N., and E. F. Neufeld. 1977. Recognition and receptor-mediated uptake of a lysosomal enzyme, $\alpha$-L-iduronidase, by cultured human fibroblasts. Cell. 12:619-627.

37. Von Figura, K., and A. Hasilik. 1986. Lysosomal enzymes and their receptors. Annu. Rev. Biochem. 55:167-193.

38. Morgan, D. O., J. C. Edman, D. N. Standring, V. A. Fried, M. C. Smith, R. A. Roth, and W. J. Rutter. 1987. Insulin-like growth factor II receptor as a multifunctional binding protein. Nature (Lond.). 329:301-307.

39. Kiess, W., G. D. Blickenstaff, M. M. Sklar, C. L. Thomas, S. P. Nissley, and G. G. Sahagian. 1988. Biochemical evidence that the type II insulin-like growth factor receptor is identical to the cation-independent mannose 6-phosphate receptor. J. Biol. Chem. 263:9339-9344.

40. Tong, P. Y., S. E. Tollefsen, and S. Kornfeld. 1988. The cation-independent mannose 6-phosphate receptor binds insulin-like growth factor II. J. Biol. Chem. 263:2585-2588.

41. Reuser, A. J. J., M. A. Kroos, N. J. Ponne, R. A. Wolterman, M. C. B. Loonen, H. F. M. Busch, W. J. Visser, and P. A. Bolhuis. 1984. Uptake and stability of human and bovine acid $\alpha$-glucosidase in cultured fibroblasts and skeletal muscle cells from glycogenosis type II patients. Exp. Cell. Res. 155:178189.

42. Van der Ploeg, A. T., M. C. B. Loonen, P. A. Bolhuis, H. F. M. Busch A. J. J. Reuser, and H. Galjaard. 1988. Receptor-mediated uptake of acid $\alpha$-glucosidase corrects lysosomal glycogen storage in cultured skeletal muscle. Pediatr. Res. 24:90-94.

43. Van Diggelen, O. P., A. T. Hoogeveen, P. J. Smith, A. J. J. Reuser, and H Galjaard. 1982. Enhanced proteolytic degradation of normal $\beta$-galactosidase in the lysosomal storage disease with combined $\beta$-galactosidase and neuraminidase deficiency. Biochim. Biophys. Acta. 703:69-76.

44. Reuser, A. J. J., M. A. Kroos, R. P. J. Oude Elferink, and J. M. Tager 1985. Defects in synthesis, phosphorylation and maturation of acid $\alpha$-glucosidase in glycogenosis type II. J. Biol. Chem. 260:8336-8341.

45. Mutsaers, J. H. G. M., H. Van Halbeek, J. F. G. Vliegenthart, J. M. Tager, A. J. J. Reuser, M. A. Kroos, and H. Galjaard. 1987. Determination of the structure of the carbohydrate chains of acid $\alpha$-glucosidase from human placenta Biochim. Biophys. Acta. 911:244-251.

46. Van Ewijk, W., J. H. M. Verzijden, T. H. van der Kwast, and S. W. M Luijcx-Meijer. 1974. Reconstitution of the thymus dependent area in the spleen of lethally irradiated mice. Cell Tiss. Res. 149:43-60.

47. Lowry, O. H., N. J. Rosebrough, A. L. Farr, and R. J. Randall. 1951 Protein measurement with the Folin phenol reagent. J. Biol. Chem. 193:265-275. 48. Galjaard, H. 1980. Genetic Metabolic Diseases. Early Diagnosis and Prenatal Analysis. Elsevier Science Publishers B. V./North-Holland Publishing Co., Amsterdam and New York. 809-810.
49. De Jonge, A. J. R., S. de Smit, M. A. Kroos, and A. J. J. Reuser. 1985. Cotransfer of syntenic human genes into mouse cells using isolated metaphase chromosomes or cellular DNA. Hum. Genet. 69:32-38.

50. Laemmli, U. K. 1970. Cleavage of structural proteins during the assembly of the head of bacteriophage T4. Nature (Lond.). 227:680-685.

51. Towbin, H., T. Staehelin, and J. Gordon. 1979. Electrophoretic transfer of proteins from polyacrylamide gels to nitrocellulose sheets: procedure and some applications. Proc. Natl. Acad. Sci. USA. 76:4350-4354.

52. Van der Ploeg, A. T., A. M. M. Van der Kraaij, R. Willemsen, M. C. B. Loonen, J. F. Koster, and A. J. J. Reuser. 1990. Rat heart perfusion as model system for enzyme replacement therapy in glycogenosis type II. Pediatr. Res. 28:344-347.

53. Willemsen, R., H. A. Wisselaar, and A. T. Van der Ploeg. 1990. Plasmalemmal vesicles are involved in trans-endothelial transport of albumin, lysosoma enzymes and mannose 6-phosphate receptor fragments in capillary endothelium Eur. J. Cell Biol. 51:235-241.

54. Shepherd, V. L., and P. D. Stahl. 1984. Macrophage receptors for lysosomal enzymes. In Lysosomes in Biology and Pathology. Vol. 7. J. T. Dingle R. T. Dean, and W. Sly, editors. Elsevier Science Publishers B. V., Amsterdam. 83-98.

55. Von Specht, B. U., B. Geiger, R. Arnon, J. Passwell, G. Keren, B. Goldman, and B. Padeh. 1979. Enzyme replacement in Tay-Sachs disease. Neurology. 29:848-854

56. Rattazzi, M. C., S. B. Lanse, R. A. McCullough, J. A. Nester, and E. A Jacobs. 1980. Towards enzyme replacement in GM2 gangliosidosis: organ disposition and induced central nervous system uptake of human $\beta$-hexosaminidase in the cat. In Enzyme Therapy in Genetic Diseases:2. R. J. Desnick, editor. Alan R. Liss, Inc., New York. 179-193.

57. Brot, F. E., C. E. Bell, and W. S. Sly, 1978. Purification and properties of $\beta$-glucuronidase from human placenta. Biochemistry. 17:387-391.

58. Tager, J. M., M. N. Hamers, A. W. Schram, F. A. J. T. M. Van Den Bergh, P. J. G. M. Rietra, C. Loonen, J. F. Koster, and R. Slee. 1980. An appraisal of human trials in enzyme replacement therapy of genetic diseases. In Enzyme Therapy in Genetic Diseases. Birth Defects Original Article Series. Vol. 16. R. J. Desnick, editor. Alan R. Liss Inc., New York. 343-359.

59. Hoefsloot, L. H., M. Hoogeveen-Westerveld, M. A. Kroos, J. Van Beeumen, A. J. J. Reuser, and B. A. Oostra. 1988. Primary structure and processing of lysosomal $\alpha$-glucosidase; homology with the intestinal sucrase-isomaltase complex. EMBO (Eur. Mol. Biol. Organ.) J. 7:1697-1704.

60. Barton, N. W., F. S. Furbish, G. J. Murray, M. Garfield, and R. O. Brady. 1990. Therapeutic response to intravenous infusions of glucocerebrosidase in a patient with Gaucher disease. Proc. Natl. Acad. Sci. USA. 87:1913-1918. 